\title{
Kimura Disease: Cervical, Supraclavicular and Mediastinal Lymphadenopathy Mimicking Lymphoma
}

\section{Kimura Hastalığı: Lenfomayı Taklit Eden Servikal, Supraklavikular ve Mediastinal Lenfadenopati}

Cenk Balta', Mustafa Kuzucuoğlu², Eren Altun ${ }^{3}$

\section{Abstract}

Kimura disease is rarely seen benign chronic inflammatory disease, the etiology of which is unknown. The diagnosis of the disease is challenging, and so histopathological sampling is necessary. Eosinophilia, increased serum immunoglobulin $E$ levels and subcutaneous nodules in the head and neck are the classical triad indicators of the disease. Herein, we present the case of a 33-year-old man with multiple lymphadenopathies in the area of neck, supraclavicular and mediastinum. The patient was pre-diagnosed with lymphoma. After a supraclavicular lymph node excision, the diagnosis was re-evaluated as Kimura Disease.

Key words: Kimura Disease, lymphoma, immunoglobulin E, Eosinophilia.

\section{Özet}

Kimura hastalığı nadir izlenen benign kronik inflamatuar bir hastalıktır ve etyolojisi belirsizdir. Tanı koymak oldukça zor ve tanıda doku örneklemesi gereklidir. Eozinofili, artmış serum immunoglobulin E değerleri ve baş ve boyunda subkutan nodüller klasik triadını oluşturmaktadır. Burada, servikal, supraklavikular ve mediastende multiple lenfadenopati ile başvuran 33 yaşında bir hastayı sunduk. Olgumuz lenfoma ön tanısıyla danışıldı. Supraklavikular lenf nodu eksizyonu sonrasında Kimura Hastalığı olarak tanı konuldu.

Anahtar Sözcükler: Kimura Hastalığı, lenfoma, Immunoglobulin E, Eosinofili.
'Department of Thoracic Surgery, Balıkesir University, Balıkesir, Turkey

${ }^{2}$ Department of Thoracic Surgery, İzmir Katip Çelebi University, İzmir, Turkey

${ }^{3}$ Department of Pathology, Balıkesir University, Balıkesir, Turkey
'Balıkesir Üniversitesi Tıp Fakültesi, Göğüs Cerrahisi Ana Bilim Dalı, Balıkesir

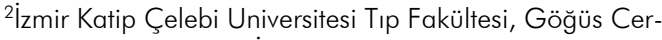
rahisi Ana Bilim Dalı, İzmir

${ }^{3}$ Balıkesir Üniversitesi Tıp Fakültesi, Patoloji Ana Bilim Dalı, Balıkesir

Submitted (Başvuru tarihi): 21.04.2020 Accepted (Kabul tarihi): 02.06.2020

Correspondence (iletişim): Cenk Balta, Department of Thoracic Surgery, Balıkesir University, Balıkesir, Turkey

e-mail: drcenkbalta@gmail.com 
Kimura disease (KD) is a rare, benign disorder that usually manifests with painless subcutaneous soft tissue swellings and/or lymphadenopathy in Asian males aged between 20 and 30 years (1). Common localizations are the head and neck, including the salivary glands and lymph nodes. Eosinophilia and increased levels of serum immunoglobulin (lg) $E$ are other components of this disorder (2).

The etiology is still unknown, although there are hypotheses of trauma, allergic reaction, autoimmune response and viral or parasitic paths (3). To clarify the diagnosis, a histopathological examination and lymph node biopsy must be performed. The treatment modality is still unclear. The preferred method is surgical excision, but in large and/or multiple masses, or to avoid recurrence, radiotherapy and immunosuppressive therapy are referred to as additional methods (2).

We present here the case of a 33-year-old male with a complaint of swelling mimicking lymphoma in the right supraclavicular area who was diagnosed with KD following an excisional biopsy.

\section{CASE}

A 33-year-old man was admitted to our clinic with a prediagnosis of an anterior mediastinum mass. A physical examination revealed a pruritic multiple cervical and supraclavicular lymphadenopathy (Figure 1). No fever, night sweats or weight losses were detected in a clinical examination.

Laboratory values were as follows: White Blood Cell

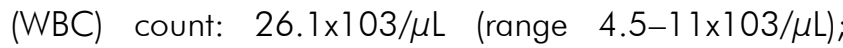
hemoglobin (HGB): $12.7 \mathrm{~g} / \mathrm{dL}$ (range $13.1-17.2 \mathrm{~g} / \mathrm{dL}$ ); neutrophil count: $23 \times 103 / \mu \mathrm{L}$ (range $1.9-8 \times 103 / \mu \mathrm{L}$ ) with $88.4 \%$ (range 40-74); eosinophil count: $0.7 \times 103 / \mu \mathrm{L}$ (range $0-0.2 \times 103 / \mu \mathrm{L}$ ) with $3.5 \%$ (range $0-7$ ); serum Creactive protein (CRP): $172 \mathrm{mg} / \mathrm{L}$ (range $0-5 \mathrm{mg} / \mathrm{L}$ ); erythrocyte sedimentation rate (ESR): $86 \mathrm{~mm} / \mathrm{h}$ (range $0_{-}$ $15 \mathrm{~mm} / \mathrm{h}$ ); total $\mathrm{lgE}: 527.8 \mathrm{lU} / \mathrm{mL}$ (range 0-100 $\mathrm{IU} / \mathrm{mL}$ ); and serum lgG: $21.3 \mathrm{~g} / \mathrm{dL}$ (range $7-16 \mathrm{~g} / \mathrm{dL}$ ). Liver and renal function tests were normal. Serology tests were performed to rule out viral hepatitis, HIV, CMV and EBV. An enlargement in the upper mediastinum and a right deviation of the trachea was detected in a chest radiograph (Figure 2a). Multiple lymphadenopathy involving cervical, supraclavicular and prevasculary mediastinal areas were detected upon a computed tomography (CT) (Figure $2 \mathrm{~b}$ and c). An ultrasonography showed a heterogeneous lobulated solid conglomerate lymphadenopathy measuring $43 \times 23 \mathrm{~mm}$ in diameter in the right supraclavicular area.

A fine needle aspiration biopsy was performed, and a cytological examination showed fibrous connective tissue with rare lymphoid infiltrates and increased eosinophil. Kimura disease and angiolymphoid hyperplasia with eosinophilia were also investigated in a differential diagnosis. We decided to perform cervical lymph node excision to clarify the diagnosis, and the enlarged lymph node was reported by the histopathology department to be fibrous tissue involving eosinophilic inflammation on a fibrohistocytic ground, centered on necrotizing areas. The tissue was compatible with KD (Figure 3), and the diagnosis was confirmed by the increased serum levels of $\lg E$ and eosinophilia.

The patient underwent corticosteroid therapy (prednisone: $0.5 \mathrm{mg} / \mathrm{kg} / \mathrm{day})$, and the lymphadenopathy and eosinophilia decreased gradually in the first month of follow up.

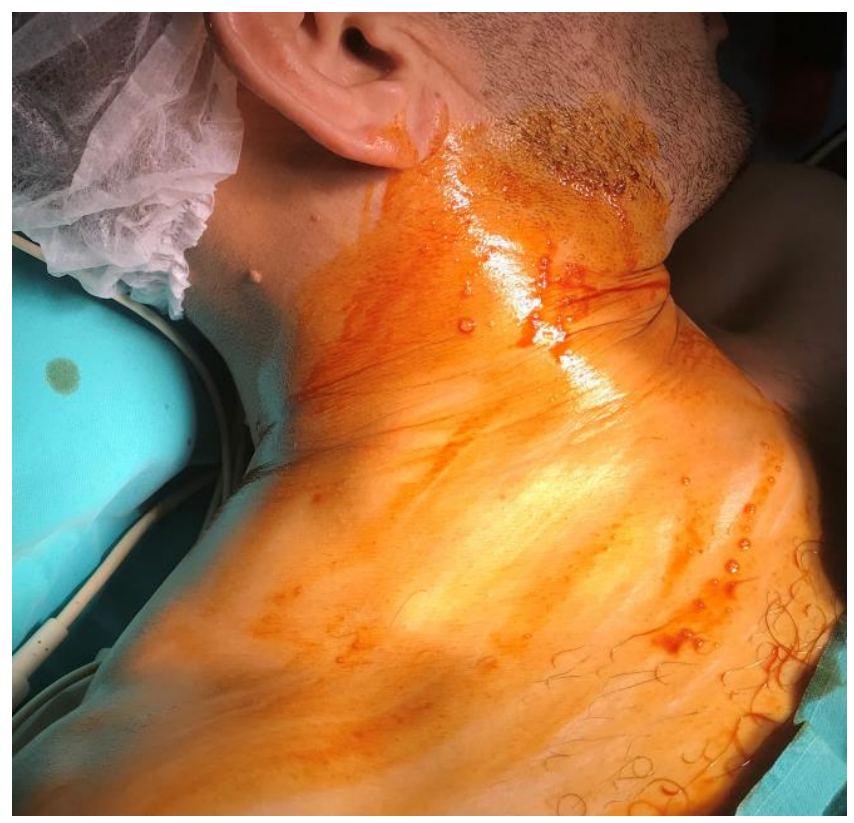

Figure 1: View of lymphadenopathy in the right supraclavicular area

\section{DISCUSSION}

KD was first described by Kim in 1937, but was more widely recognized after the publication of Kimura's study in $1948(4,5)$. It is a rare and benign disease involving subcutaneous tissue and lymph nodes. The lesion may be pruritic and painless. KD is endemic to the Asia region, although non-Asian cases have also been published $(1,6)$. It is usually seen in men, with a male to female ratio of 19:1 (7). Our patient was 33-year-old Caucasian male with a pruritic right cervical lymphadenopathy. 


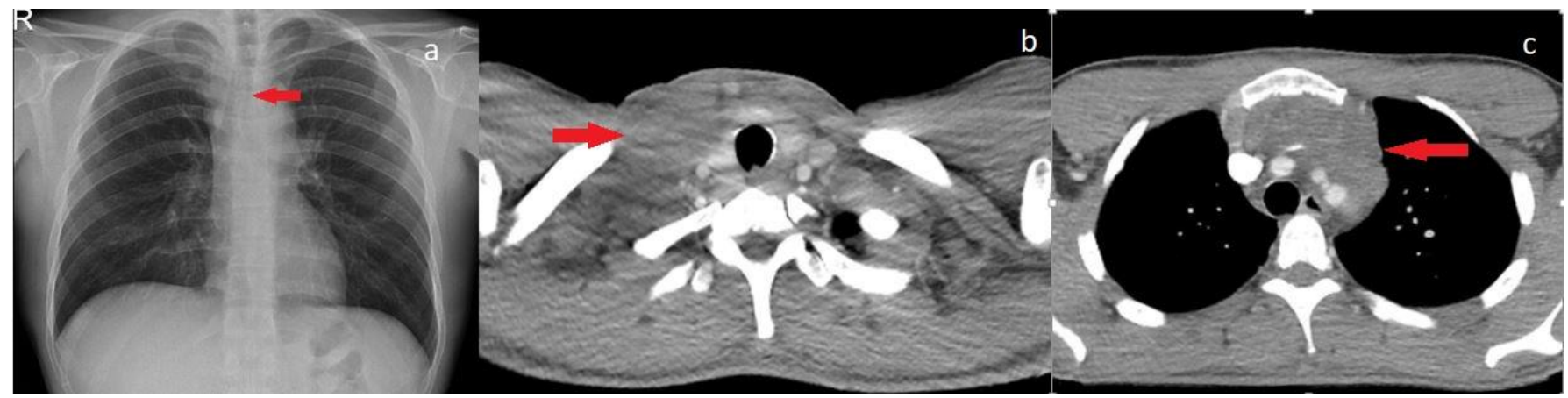

Figure 2a, b and c: Tracheal deviation in a chest X-ray (a), enlarged lymphadenopathy in the right supraclavicular (b), prevascular mediastinal region (c)

Although the etiology is unclear, trauma, allergic reaction, autoimmune process or T-helper 2 immunoregulation, and the release of eosinophilic cytokines (IL 4, IL 5, IL 13, $\mathrm{TNF} \alpha$ ) in response to a viral or parasitic trigger, may be suspected $(2,3,6,7)$.

The initial presentation of the disease is a slow and progressive unilateral subcutaneous mass or enlarged lymph node of the head and neck area in up to $76 \%$ of patients $(2,3,8)$. Other localizations of KD are cervical, retro auricular, inguinal, in the epicranial area, eyelids, axillary area, and in the oral cavity and nasal sinuses (6). The mediastinum is rarely involved $(1,9)$.

Differential diagnoses include angiolymphoid hyperplasia with eosinophilia (ALHE), Hodgkin's disease, T-cell lymphoma, Langerhans cell histiocytosis, Castleman disease and parasitic lymphadenitis (2). Since the CT findings of lymphoma and KD are similar, a pathological examination of lymph node is essential. Eosinophilia and increased serum levels of $\mathrm{lg} E$ are mandatory for a positive diagnosis. ALHE and KD can be histopathologically similar, although fibrohistiocytic involvement and lymphoid follicles can help to differentiate between the two (6).

Although $K D$ is a local disorder, activated $T$ cells may increase the permeability of the renal glomerular membrane and cause proteinuria and nephrotic syndrome in $12-16 \%$ of patients $(1,3,6-8)$. It may present with asthma, allergic rhinitis, atopic dermatitis and peripheral eosinophilia due to the increased serum Ig E levels (9). In our case, renal functions were normal, but the patient had asthma in their childhood history.

Radiological findings is nonspecific as homogeneous lymphadenopathy and/or enlarged salivary glands $(6,8,9)$. A histopathological diagnosis is mandatory to rule out lymphoma if the mediastinal, extra pleural, epigastric, mesenteric and retroperitoneal areas are involved (8). In our case, KD presented with cervical, supraclavicular, axillary and mediastinal lymphadenopathy. The lymphoma was suspicious in a differential diagnosis.
A fine needle aspiration cytology (FNAC) is suggested as an initial diagnostic method to differentiate between malign disease and reactive hyperplasia, being more costeffective than an excision biopsy. Kapoor et al. (10), however, report FNAC to be of limited use in the diagnosis of KD. In our case, FNCA was performed on the cervical lymph node and the cytological diagnosis was inadequate.

The histopathological features of KD include follicular hyperplasia with a reactive germinal center; eosinophilic micro abscesses; germinal center necrosis; and eosinophilic infiltrates in the germinal center and sclerotic areas $(2,10)$.

Although KD is benign, the recurrence rate is high (6). The optimum treatment is unclear. Surgical excision is recommended for solitary lesions, where possible $(1,2)$. In generalized lymphadenopathy systemic corticosteroids, cytotoxic agents and irradiation may be effective $(8,9,10)$. Corticosteroids are essential if the kidneys are affected $(2,6)$. Local radiotherapy $(25-30 \mathrm{cG})$ is proposed when systemic steroids are unsuccessful. Cyclosporine, imatinib, azathioprine, leflunomide, cetirizine, pranlukast, all-transretinoic acid and cyclophosphamide are other treatment options $(2,3,6)$. Chen et al. (1 1 ) reported young age and high blood eosinophil counts to be associated with recurrence, and eosinophil count to be correlated with the size of the lymphadenopathy and the response to therapy.

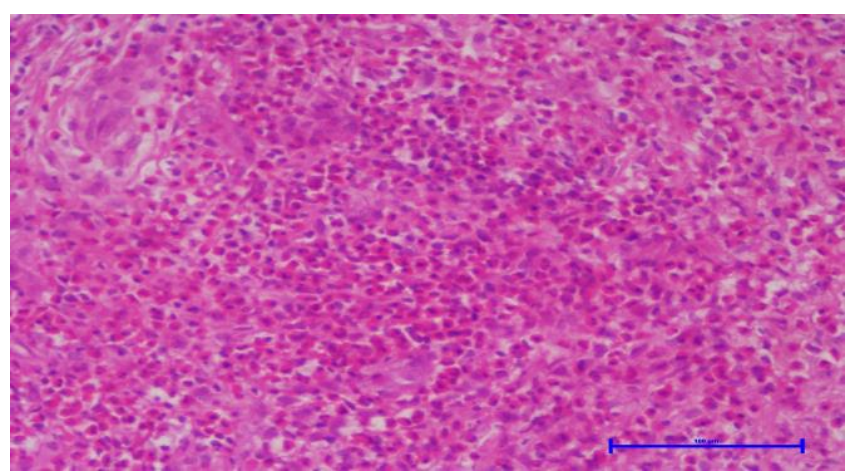

Figure 3: Eosinophilia infiltration with fibrohistocytic grounds (H\&E X200) 
In conclusion, KD is a benign lymphoproliferative disease of unknown etiology. Differentiating between KD and lymphoma can be difficult, and the treatment modality is still controversial, although surgical excision, corticosteroids, radiation therapy and cytotoxic agents are suggested.

\section{CONFLICTS OF INTEREST}

None declared.

\section{AUTHOR CONTRIBUTIONS}

Concept - C.B., M.K., E.A.; Planning and Design - C.B., M.K., E.A..; Supervision - C.B., M.K., E.A.; Funding C.B., M.K., E.A.; Materials - C.B., M.K., E.A.; Data Collection and/or Processing - C.B., M.K.; Analysis and/or Interpretation - C.B., M.K.; Literature Review - C.B., M.K.; Writing - C.B., M.K.; Critical Review - C.B., M.K.

\section{YAZAR KATKILARI}

Fikir - C.B., M.K., E.A.; Tasarım ve Dizayn - C.B., M.K., E.A.; Denetleme - C.B., M.K., E.A.; Kaynaklar - C.B., M.K., E.A.; Malzemeler - C.B., M.K., E.A.; Veri Toplama ve/veya İşleme - C.B., M.K.; Analiz ve/veya Yorum - C.B., M.K.; Literatür Taraması - C.B., M.K.; Yazıyı Yazan - C.B., M.K.; Eleştirel İnceleme - C.B., M.K.

\section{REFERENCES}

1. Yang TH, Chou YH, Kao WY, Cherng SC. Kimura disease simulating Hodgkin's lymphoma on (18)F FDG PET/CT: report of a case Nucl Med Mol Imaging 2014; 48:313-6. [CrossRef]

2. Rodrigues $G$, Ravi B. Synchronous Kimura lesions at two different sites-a diagnostic dilemma! Quant Imaging Med Surg 2016; 6:214-7. [CrossRef]
3. Shena ML, Nagarajan VP, Karmegaraj B, Rao S, Manipriya R, Scott JX. Kimura's disease: a rare cause of chronic lymphadenopathy in a child. Malays J Med Sci 2015; 22:69-72.

4. Kim HT, Szeto C. Eosinophilic hyperplastic lymphogranuloma: comparison with Mikulicz's disease. Chin Med J 1937; 23:699-700.

5. Kimura T, Yoshimura S, Ishikawa E. Unusual granulation combined with hyperplastic changes of lymphatic tissue. Transl Soc Pathol Jpn 1948; 37:179-80.

6. García Carretero R, Romero Brugera M, RebolloAparicio N, Vazquez-Gomez O. Eosinophilia and multiple lymphadenopathy: Kimura disease, a rare, but benign condition. BMJ Case Rep 2016; $31 ; 2016$ :bcr2015214211. [CrossRef]

7. Wang DY, Mao JH, Zhang Y, Gu WZ, Zhao SA, Chen YF, et al. Kimura disease: a case report and review of the Chinese literature. Nephron Clin Pract 2009; 111 :c5561. [CrossRef]

8. Sun $Q F, X u D Z$, Pan SH, Ding JG, Xue ZQ, Miao CS, et al. Kimura disease: review of the literature. Intern Med J 2008; 38:668-72. [CrossRef]

9. Hobeika CM, Mohammed TL, Johnson GL, Hansen K. Kimura's disease: case report and review of the literature. J Thorac Imaging 2005; 20:298-300. [CrossRef]

10. Kapoor NS, O'Neill JP, Katabi N, Wong RJ, Shah JP. Kimura disease: diagnostic challenges and clinical management. Am J Otolaryngol 2012; 33:259-62. [CrossRef]

11. Chen H, Thompson LDR, Aguilera NSI, Abbondanzo SL. Kimura disease: a clinico- pathologic study of 21 cases. Am J Surg Pathol 2004; 28:505-13. [CrossRef] 